\title{
EDUCATION FOR GOVERNMENT
}

\section{A} DEBATE on the motion "That the education of our future rulers should be primarily in the sciences rather than the humanities" was held in the Beveridge Hall, Senate House, University of London, on March 18. Sir Cyril Hinshelwood was in the chair; the motion was proposed by Sir Alexander Fleck, seconded by Prof. A. R. Ubbelohde, and opposed by Prof. B. Farrington, seconded by Prof. W. Beare. The debate was sponsored jointly by the London Section of the Royal Institute of Chemistry, the London branch of the Classical Association and the Haldane Society.

Sir Cyril remarked, in opening the proceedings, that he supposed he owed his position on the fence on this oecasion to the fact that he happened to be president of the Classical Association as well as president of the Royal Society. He asked that there should be a straight fight on the arts versus science issue implied in the motion, but in this he must have been rather disappointed. Scarcely a speaker could be found to defend the motion as worded, and it was necessary even for Sir Alexander Fleck to assure his audience that whatever he might say, he was, in fact, moving the motion. His reluctance to do so stemmed not only from his slender acquaintance with the classies--failures in Latin having on two occasions "almost wrecked an otherwise promising career" - but from his dislike of the term "our future rulers". Any suggestion of a Platonic élite, selected by some process of intellectual eugenics, was repug. nant to him. But there was an urgent need to orient the education of the people as a whole so that the statesmen and leaders they produced would be capable of handling scientific ideas. He contrasted, not too seriously, the legendary pedantry and otherworldliness of the classical scholar, with the severely practical, positive approach which a scientific training could bring to the consideration of human affairs. $\mathrm{He}$ believed, with Lord Cherwell, that it was more important to know something of the properties of chlorine than of the improprieties of Clodius. The continued growth of science and of informed opinion about science was vital to our country and to all peoples.

Prof. Benjamin Farrington, in a persuasive speech, opposed the motion on the grounds that it appeared to imply that there should be a compulsory tilt in the whole educational system so as to give primary emphasis to science. He had no quarrel with science -we should spend even more of our resources upon it in the future than we do at present-but it was essential that science remained the servant, not the master. The transformation of human life by science in the past three hundred years had been remarkable, but it had produced problems to which science by itself had no answers. The problems raised by auto. mation, for example, or the whole question of man's survival, were beyond purely scientific answers. The humanist could survey the whole development of the marvellous being we called Man. This did not imply a backward-looking philosophy: it was the only hopeful way of looking to the future. Man alone had the power of ereating his own inner world, the world of ideas, and he had drastically ehanged life on earth by his rational acts. The human intellect was the greatest force in the universe, since it alone could produce change. Science was one of man's achievements, but it was not the only one of significance. Scientists often seemed excitable, unstable, and at the mercy of every new idea. They were apt to be misled into new superstitions and to confuse their abstractions and concepts with reality. Hence one heard of discussions about the psychology of the man-made machine, when no machine could possess consciousness. The study of conditioned reflexes in organisms was important, but they did not supersede the rational acquisition of knowledge. The humanist was concerned with the conscience of man, in which is enshrined all the long history of man's endeavour ; he must remain master.

Prof. A. R. Ubbelohde was prevented from being present by illness and his speech in support of the motion was read for him. The role of science had changed completely since the time when Dr. Johnson had ruled that "speculations upon matter are voluntary, and at leisure". It was necessary to continue the age-old process of adapting the content of education to the requirements of a changing society and admit science to the priority. A knowledge of science should be as fundamental an element of education in the future as were reading, writing and arithmetic to-day. Our future leaders would be at a disadvantage if they had not had scientific training; to understand and control the power of science would be one of their prime responsibilities. We could not risk that the potentialities of applied science should be at the mercy of "humanistic Druids" whose sympathies lay wholly outside the sciences. Scientific knowledge now formed one of the major empires of the human intellect; its disciplines threw new light upon old problems of human existence. The scientist soon learnt a humility in the face of objective facts which would stand many a politician in good stead. $\mathrm{He}$ was also accustomed to co-operating with his fellows across national boundaries in an international community of endeavour. There were dangers in too narrow an approach in scientific studies, as there were in all academic studies, but these were recognized and could be avoided. It would be a far greater danger to leave our future rulers in ignorance of science.

Prof. W. Beare, in seconding the opposition, said that the fact that they were debating this motion showed that there was a widespread uneasiness about the objects of education. Since there was no clear answer it was important to preserve freedom of choice. The idea that the education of the whole community should be compulsorily slanted was dangerous. It were better that a man should be a first-rate historian than a second-rate chemist. Our citizens and voters would be better guided by a knowledge of history than of quantitative seience, but the study of any subject could not, of itself, make a good citizen or ruler-it was the knock-about of everyday life which was the true education. $\mathrm{He}_{\ominus}$ did not grudge the scientists their palatial new premises, even though a new hat-rack might prove to be more than could be managed for the arts faculty. But a knowledge of thermodynamies would tell you nothing about hell-fire; our rulers should come from the humanists who had studied the 
imperfections and sins of man, as well as his potentialities.

When the discussion was thrown open it soon became clear that the motion had found few friends. The first two speakers were classicists; Dr. R. E. Witt spoke from experience as a headmaster of a grammar school and said that the study of Greek seemed to produce a greater humility, a greater readiness to look on the other side of a problem, than the study of seientific subjects. Mrs. M. Lockwood suggested that our leaders should have a humanistic philosophy within which their problems could be judged. Scientific progress seemed frighteningly aimless and uncontrolled; there was a suspicion that the real spur to our scientific effort was simply fear of the U.S.S.R. Prof. Timonen, of the University of Helsinki, pointed out that some of the greatest scientists had had a sound classical education and that this had probably contributed to their elarity of thought and expression.

There followed contributions by four chemists, but only one favoured the motion. Dr. A. C. C. Newman urged the importance of inculcating moral values during the education of the citizen. Political leaders had to deal with issues which were primarily moral and human; so long as they were well advised on scientific questions that was enough. Dr. H. J. Barber suggested that the study of the history of science could provide a valuable synthesis of the humanities and the sciences ; it should take its place in curricula along with political history. Mr. R. A. Frazer disliked the suggestion that the sciences should predominate in education - a balance should be struck with emphasis primarily on the humanities. Mr. F. F. Ross agreed that the learning of Latin was a valuable discipline in primary education, but it should give way to science later. An understanding of man's scientific progress was basic to the study of history.

Prof. Farrington, in replying for the opposition, deplored the fact that the necessary expansion of the science faculties of British universities had been accompanied by drastic reductions in the facilities for studying ancient and modern languages and cultures. This whs bringing about an undesirable change in the character of the universities themselves.

Sir Alexander Fleck, summing up for the motion, strenuously denied that the motives for the expansion of science were political. Man might not live by bread alone, but bread was still a necessity, and it was up to science to provide it. Only if our leaders understood science could it be used to improve life on earth.

Sir Cyril Hinshelwood then put the motion to the meeting and it was heavily defeated. A vote of thanks to the chairman and the speakers, proposed by Dr. S. A. Miller, was carried with acclamation.

N. Lindor

\section{DETERGENTS, TEXTILES AND DYES}

\begin{abstract}
A CONFERENCE on "Detergents, Textiles and Colour", organized by the. Textile Institute in collaboration with the Branded Textiles Group, was held on February 11 in the Lesser Free Trade Hall, Manchester. Mr. Roland Thomas (director, C.P.A., Ltd., Branded Textiles Group), opening the meeting, said that the products produced by the Group were guaranteed and that members of the Group were interested in maintaining high quality in a very large range of textile goods. Serious consideration had been given for two and a half years to problems arising from the new detergents; on the subject of deterioration of textiles, the detergent manufacturers' attitude to complaints had been that: (a) they were not true, $(b)$ if true, it did not matter, (c) if it did matter, nothing could be done about it, and $(d)$ if anything could be done, it would be too expensive. The problem was serious, the housewife was lost in the complexities of advertisements and it was the business of industry to find a solution.
\end{abstract}

In the morning three papers were read and a number of excellent demonstrations shown to illustrate loss of tint by lack of fastness of dyes to detergent mixtures, by contamination by fluorescent bleaches and by chemical bleaching.

Mr. C. F. Ward (on behalf of the Branded Textiles Group) referred to the great increase in recent years in the number and variety of textiles and also of detergents and substances added to the synthetic soaps. It was fortunate, he said, that in this change emphasis has been placed by the textile manufacturer more and more upon quality. He listed detergent requirements and mentioned the need for instructions understandable by the non-technical housewife. Detergent compositions were discussed, particularly the so-called optical bleaches-the colourless blue- fluorescing substances used to give the "whiter-thanwhite" look. The danger of transfer of these substances from one article to another in the wash was pointed out and, in particular, the most objectionable effect apon the tint of textiles originally dyed to pastel shades such as peach and nil which, after contamination by the fluorescent optical bleach, appear pink and dirty blue.

Complaints of faults caused by the chemical bleach in the detergent powder, such as 10 per cent sodium perborate, were described; in particular of a royal blue dye on wool which develops yellow patches and spots at temperatures as low as $110^{\circ} \mathrm{F}$. Cellulosic materials develop pin-holes either through the action of particles of the bleach which have not been completely dissolved, or through local traces of metal catalysts causing violent action by the dissolved persalt. Fading of dyes in sunshine while drying on the line may be attributed to incomplete rinsing of alkali. Some optical bleaches are themselves not fast to light and discolour in sunlight. The quite common practice of the housewife adding bleach containing chlorine to a detergent when washing whites leads to further troubles; Mr. Ward said that he understood that organic chloro-compounds are already being added to domestic washing powders in the United States and are being considered for use in Great Britain. He viewed this with the greatest concern, since it would lead to increase of complaints of loss of colour, fading, local bleaching, and loss of wear.

Mr. Ward concluded by saying that the housewife is puzzled by the number of products and the various claims made for them; whereas he had no objection to optical bleaches for those who want them for whites, he did complain that colours of textiles are 